\title{
Behind the Walls: Manifestations of Place and Space at COP21
}

\author{
ROOPALi PHADKE ${ }^{1}$ \\ Macalester College
}

Right after Thanksgiving, I boarded a plane with ten undergraduate students from my "Climate Talks" course and headed to Paris for the $21^{\text {st }}$ Conference of the Parties of the UN Framework Convention on Climate Change (UNFCCC - COP21). It was the culmination of a semester studying the history of climate politics and past COP meetings, the rituals of negotiation and Skyping with many STS scholars who study the field. Once in Paris, students fanned out over the "green" civil society and "blue" diplomatic zones tracking down interviews, observing press conferences and striking up conversation in lunch lines with delegates from around the world.

My role was to facilitate the student experience and network with other members of the RINGO constituency (research institutions and NGOs). We made great connections and met amazing higher education delegations. While I had some minor research goals, I had the freedom to wander eyes wide open throughout the COP space and notice how this very unusual kind of conference unfolds.

This was my first COP. I'll admit that I was mostly expecting to spend my time watching the delegates quarrel over negotiating the text. Instead, I found myself drawn to exploring the parts of the Paris summit that seemed to me-and here I am referencing a phrase by a colleague - like a hybrid between a county fair and an esoteric academic conference. As a newcomer, I was most impressed that a successful COP is as much about having a command of place and space as it is about negotiating bracketed text.

My first observation is that an effective COP requires an inviting negotiating place. I give the French a lot of credit for what they pulled off at Le Bourget, the site of a regional airport in suburban Paris. It was remarkable that despite the recent terror attacks and the 46,000 people expected to be present over the two weeks, the logistics of the meeting were seamless. I am sure

\footnotetext{
1 Roopali Phadke, Email: phadke@macalester.edu

Copyright (c) 2015 (Roopali Phadke). Licensed under the Creative Commons Attribution Non-commercial No Derivatives (by-nc-nd). Available at estsjournal.org.
} 
some of the activist organizations would disagree with me since many of their events were cut out. But, from my perspective, the green aproned helpers guiding us to the trains and buses (where we once found ourselves seated on the shuttle bus next to Al Gore-yes, on public transit!), the great collaborative writing spaces, and the free apples (from food giant Carrefour) made the experience altogether pleasant.

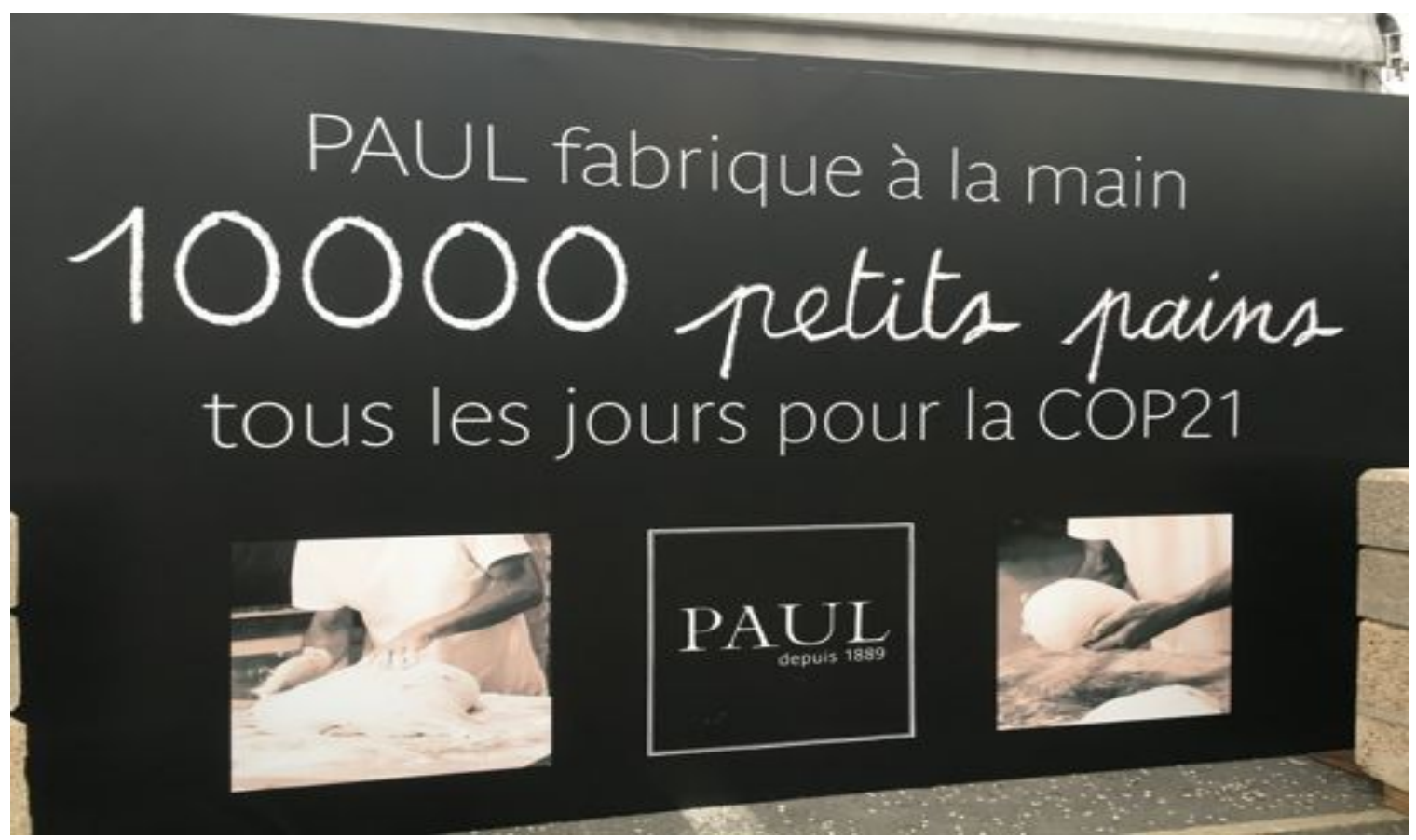

Figure 1: With an on-site bakery at COP21, the baguettes were incredibly fresh.

The COP21 site was an impressive maze of meeting rooms, cafes and media spaces, with the diplomatic zone connected to the civil society zone. The "blue zone" featured six main halls, including one for media reporting and press events and another for observer/NGO booths and meetings. There were also vast halls of closed rooms for each country's delegations to meet. The entire site had a light footprint and surprising temporality. The MDF wood walls throughout the space looked like they would knock over if a wolf huffed and puffed. The composting bins reminded us about the importance of walking the talk. It looked like IKEA furnished the entire place. My students commented to me that the whole space had a Crayola-like feel to them. The fanciful atmosphere extended to the giant neon "Noah's Ark" animals dotting the COP landscape, under which many delegates would take a break to make a phone call. 
The last time the EU hosted a UNFCCC COP was in Copenhagen in 2009. Many delegates at COP21 reflected on the damp, sad disaster that was COP15, when there was a mass walkout of green groups and representatives from developing countries. Delegates also remember that the lines were long in Copenhagen, transit slow and the halls dreary. It seems to me that the UNFCCC Secretariat and the French hosting committee knew that a successful Paris agreement required smooth logistics, wide-open spaces and a distinctive Parisian flair.

My second observation is that a country's influence at a COP is reflected in their ability to command physical space and create opportunities for public spectacle. This was evident in the number of Hollywood celebs gracing the meeting rooms and the larger than life demonstrations put on by civil society groups, like Greenpeace's giant mechanized polar bear stomping around the blue zone, or the Climate Action Network's awarding of its satirical "Fossil of the Day." In his 2011 article, Carl Death makes a similar argument about the role of spectacular theatrics at major summits and mega-events like COP15.

I found the most fascinating area of the COP site to be the hall that housed the country pavilions. This is where COP really started to feel more like visiting EPCOT, or as I have started to call it COPCOT. Not all countries pay for pavilions, but many do. Because the UNFCCC is stingy with side events, a nation's pavilion is where it can stage its own publicity and control its message - a point made by Hjerpe and Linner in their piece on COP side events. The pavilions thus serve as giant soapboxes from which nations get to tell their climate stories to other delegates, the media and observers. Indonesia's pavilion emphasized ethnic costumes. Mexico chose to feature films on biodiversity. The map in the figure below provides a sense of how some nations dominated others spatially. The lower right corner of the map shows that The Gulf Cooperation Council space, a coalition of nations including Saudi Arabia and Oman, was almost double the size of the US Center.

A brief perusal of the COP21 news media would convince most that a major feature of this COP was the US' courting of India. As a native of India, but now a citizen of the US, I was fascinated by the quiet dance going on between these nations everywhere in the COP halls, including when Modi and Obama came together to announce India would host the International Solar Alliance. 


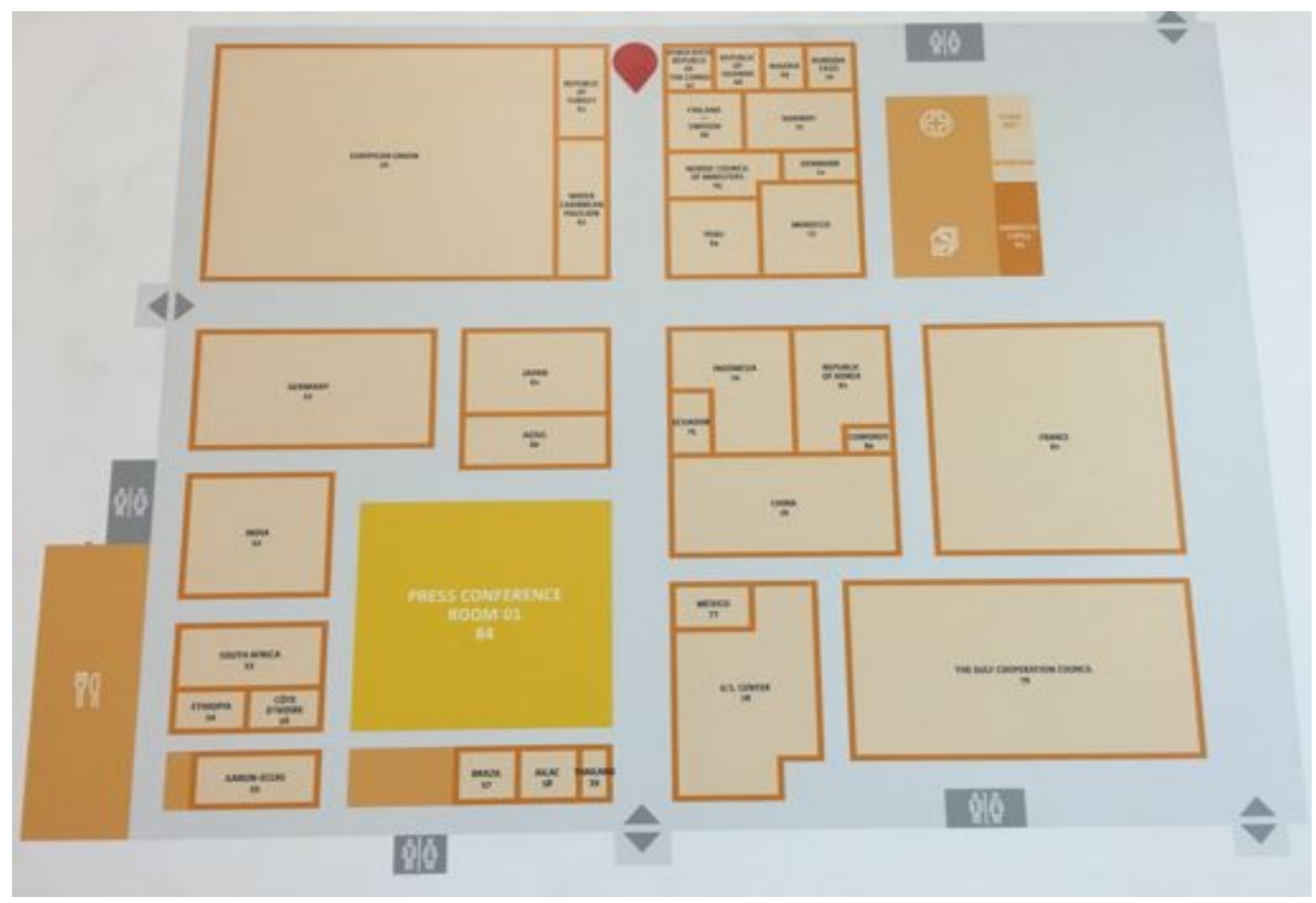

Figure 2: Locations of different country pavilions and meeting spaces.

We can get another window into their positions by looking at their unique pavilions, separated in space by a mere 100 feet. The US Center was sponsored by the State Department and featured a National Aeronautics and Space Administration (NASA) "hyperwall" of mesmerizing climate maps on one side, and the National Oceanographic and Atmospheric Agency's (NOAA) spinning Science on the Sphere on the other. A large stage centered the space, from where a steady stream of events happened each day. There was a Nespresso machine to the far side, but despite my students valiant efforts they were rarely successful at getting free coffee. 


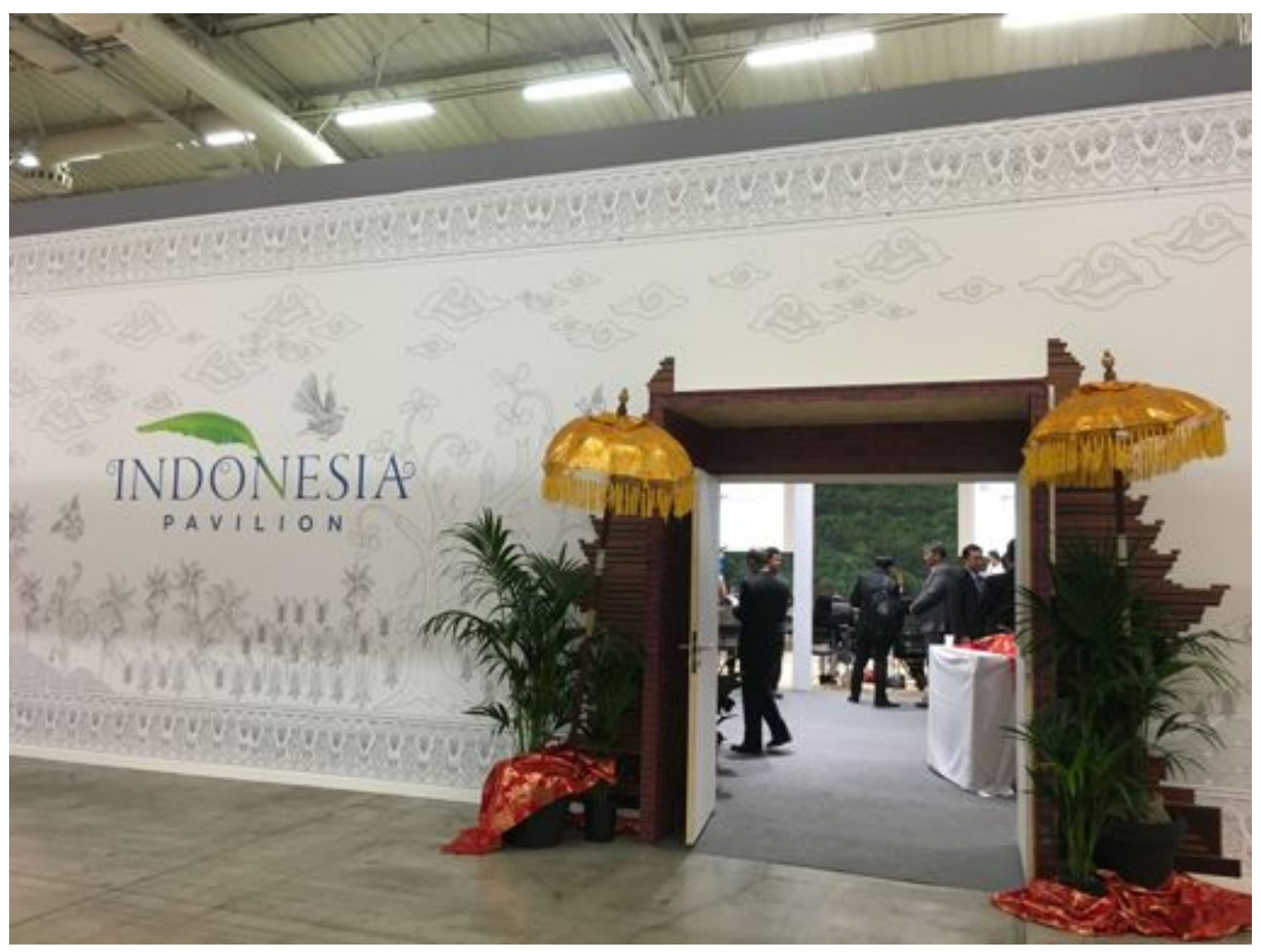

Figure 3: The Indonesia Pavilion adjacent to the Chinese Pavilion

It was from the US Center where we watched the live stream of Obama's speech, where I heard presentations from Mayors from the US and abroad, and where my students participated in a dialogue with Facebook's sustainability officers about how their platform could be leveraged for climate action (or from a cynic's point of view, how they can hold on to their youth customers in the age of Snapchat and Twitter). Yet, most of the events at the US Center featured scientists in suits and ties, often from either NASA or NOAA, talking about their computer visualizations and sophisticated data models. 


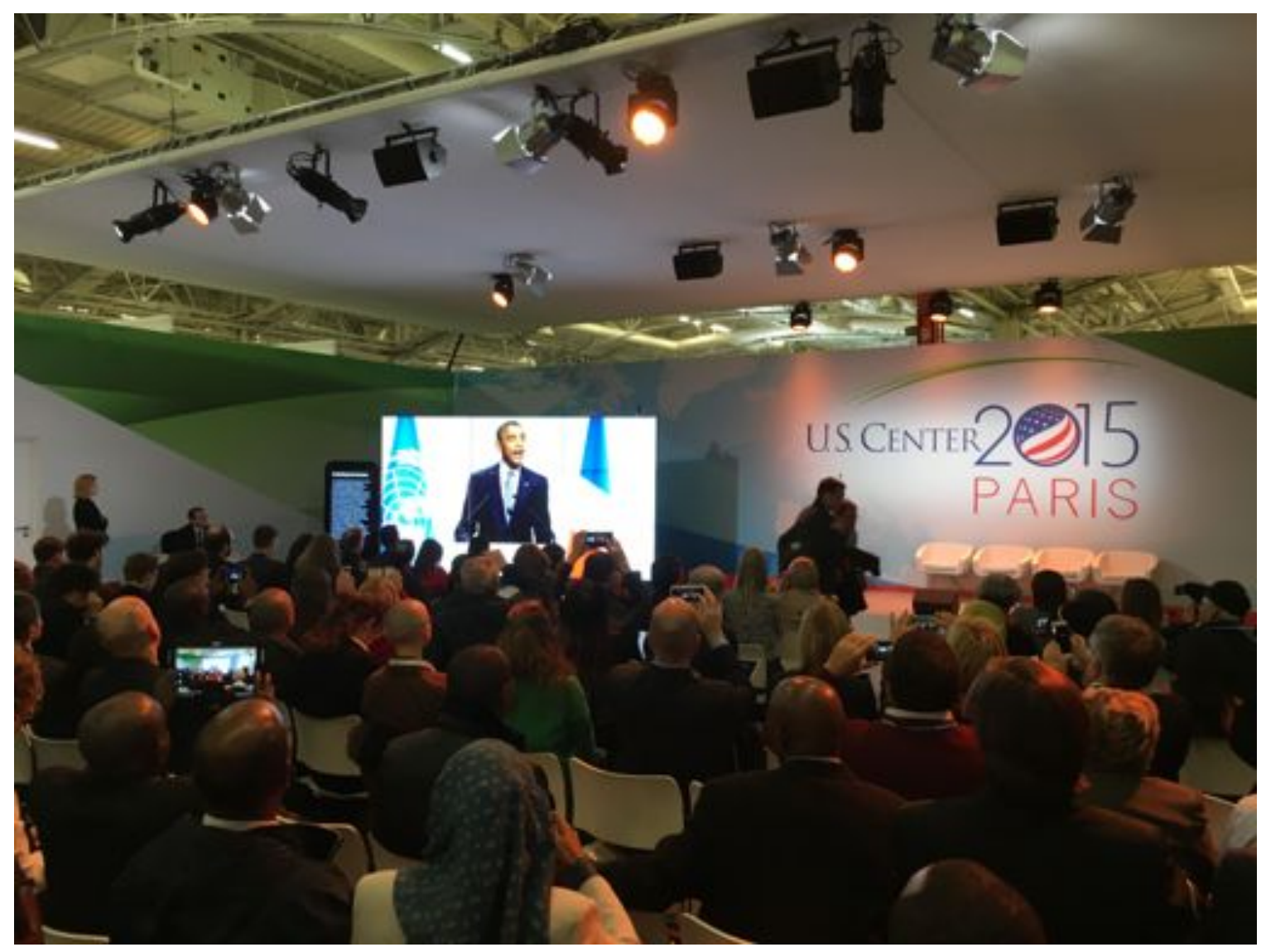

Figure 4: A packed crowd watches a live stream of President Obama's address on Day 1

I had the chance to chat with two of the women who designed and commanded the US Center. Despite their extensive climate experience and expertise, they were often found lining up the chairs and cleaning up the coffee spills. They both talked with me about the role they thought the US Center served at COP21. One talked about how they had been jealous of the EU's pavilion at a COP years ago, when they just had a small booth in comparison. They felt they needed a larger platform from which to project their leadership, especially in climate science. This helps explain the privileged presence of NASA and NOAA. The Center also included a dramatic ceiling-tofloor wall image of the Grand Canyon, and a "selfie" State Department Instagram cutout, where my students obligingly posed for me. 


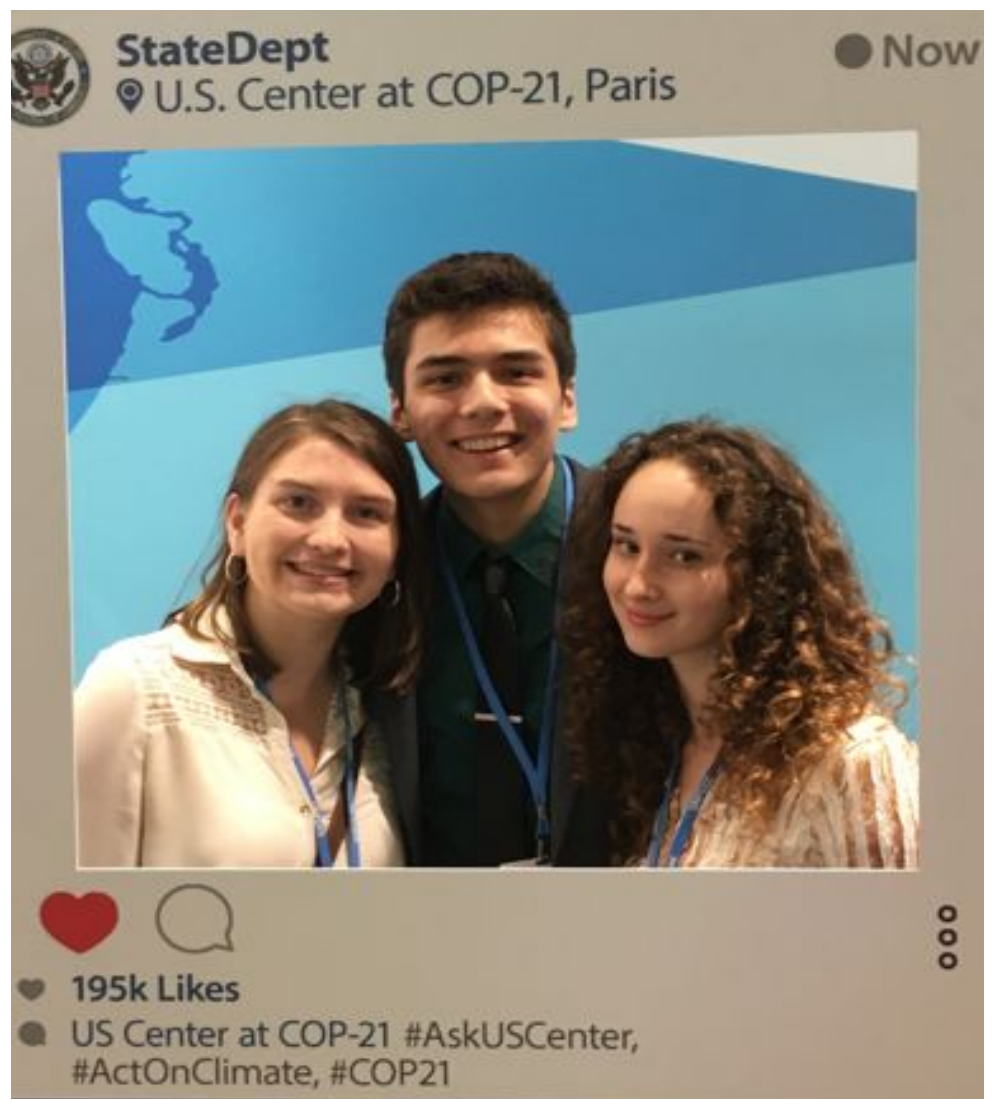

Figure 5: The author's students pose at the US Center Instagram spot

In comparison to the classroom feel of the American pavilion, the India pavilion was "the" place to get your photo taken in front of a dazzling waterfall curtain that spelled out "COP21" and drew images of wind turbines in water droplets. It reminded me of the Bellagio fountains at Las Vegas. And the waterfall curtain was just the beginning. The pavilion was meant to feel like a journey through a thousand years, beginning with the Vedas and ending in "digital" India. Interspersed throughout the space were the words "just climate action." The rumor at the conference was that India spent 1.5 million dollars on this pavilion. Behind an inconspicuous door, there was also a conference room for hosting meetings and presentations. At the US pavilion the conference room was the center stage. But, in India's, the conference room took a backseat to the water and lightshow that narrated the unfolding high tech future. One can 
imagine that these kinds of images also help convey to negotiators that India is ripe for investment in clean energy.

Prime Minister Modi had just opened the pavilion an hour before I informally interviewed the pavilion's designer. He was over the moon that Modi had loved the pavilion. He

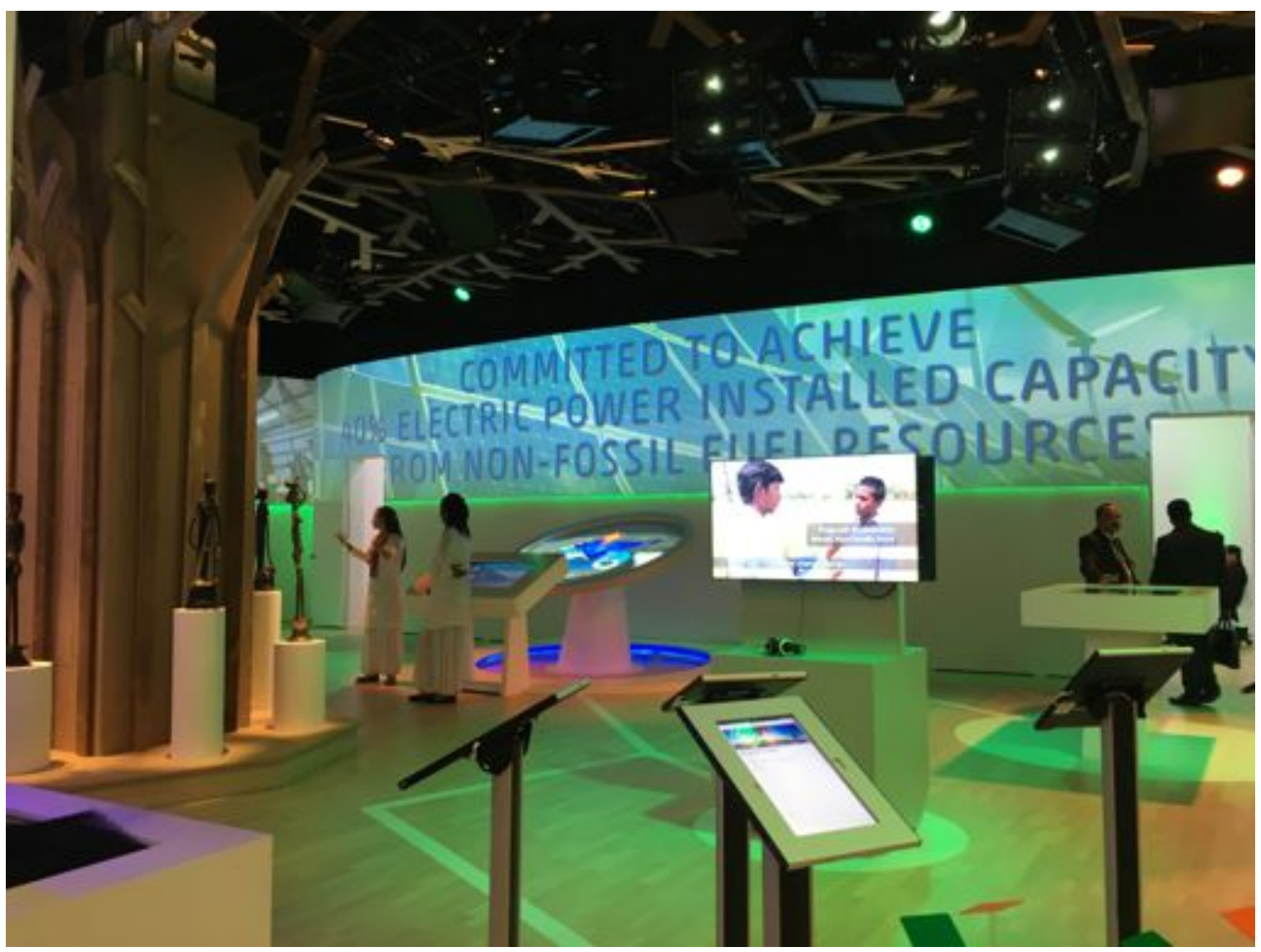

Figure 6: The expansive India Pavilion basked in a green lightshow

pointed out the digital "touch" elements throughout the space, as well as the more subtle features I had missed, like the bronze statues of tribal people on loan from India's museums, and the magnificent wood sculpture that stretched across the pavilion ceiling that meant to signify the banyan tree under which all of village life unfolds in India. The pavilion's designer referred to his desire to present India's unique form of "knowledge sharing under the tree." Whereas the US 
pavilion was about the dissemination of very technical climate data delivered by state scientists, the India space was Bollywood scale aspiration that narrated the tension between tradition and modernity, power and justice.

Yet, both the designers of the India and US pavilions had the same objective. They both wanted to project an image to delegates that contradicted the media's narrative of climate obstructionism. The US Center staff talked openly about how they know "foreigners think we don't do enough" and noted that the pavilion was about "telling our story." The virtual audience was important to them as well; the US Center was proud that they had 30,000 retweets of their first morning's message. Similarly, the India pavilion was meant to counter the image that India stands in the way of a global climate deal by screaming "We are the Solution."

However, each nation's pavilion strategically manipulated their space to create opportunities for delegates. While the US Center's large scale Grand Canyon image induced some grandeur, the space was largely set up for lectures and audience participation in very predictable, rationalist forms. In comparison, the India pavilion created an immersive visual experience for the casual visitor who, rather than walking away with facts or figures, left the pavilion with a larger-than-life sense of how India as a nation is transitioning toward a decarbonized economy.

The world now knows that a universal climate agreement was negotiated in Paris. Despite what the critics say, I think it is a historic achievement that propels us forward toward a new century of climate governance. The elite media drew our attention to the last hours of tense negotiation in the plenary venue. Yet, I believe the lesser known places and spaces of COP21 mattered as much in producing the Paris agreement. In particular, at COPCOT, images, narratives and waterfalls helped shape the imagination of delegates and observers alike. While messages of cooperation and solidarity dominated the speeches of the 150 world leaders that opened the conference, in the pavilion spaces one is reminded there is a fierce competition underway among the big nations of the world to control not only the outcome of the Paris agreement but also their own images as climate leaders. The private pavilions were places of carefully orchestrated public spectacles aimed at charting new imaginative territories. 


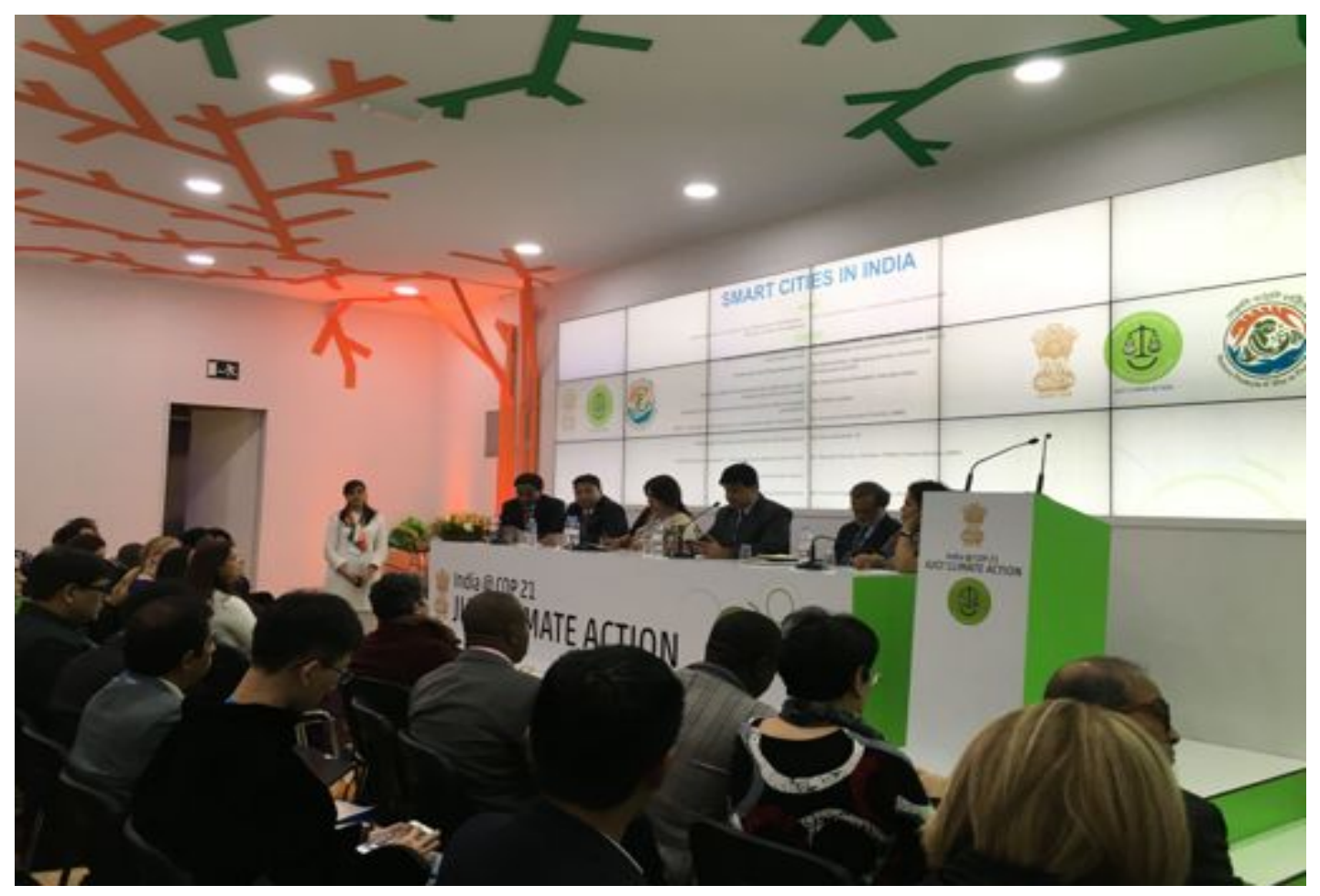

Figure 7: A Smart Cities panel hosted behind closed doors at the back of the India Pavilion

Paris will provide important lessons for future COP hosts about how to set the tone for deliberation. For academics and other observers, COP21 also draws our attention to the performative work that nation states engage in as they represent their capacity to act as global stewards. 